\title{
Recombinant soluble CCR5 AND CXCR4 chemokine receptors as anti-HIV drug targets
}

\author{
Victoria Kurbatska ${ }^{1,2^{*}}$, Zhanna Rudevica ${ }^{1,2}$, Alexander Tsimanis ${ }^{3}$, Ainars Leonciks ${ }^{1,2}$ \\ From $16^{\text {th }}$ International Symposium on HIV and Emerging Infectious Diseases \\ Marseille, France. 24-26 March 2010
}

\section{Background}

The aim of current work was to produce recombinant soluble CCR5 and CXCR4 chemokine receptors that could be used in screening of potential HIV-1 inhibitors.

\section{Methods}

Recombinant DNA constructs were produced by using polymerase chain reaction (PCR) technique and cloning. Proteins were expressed in bacteria and purified using immobilized metal ion affinity chromatography. To validate functionality of the recombinant proteins immunoprecipitation, immunblot and ELISA assays were performed.

\section{Results}

We designed recombinant soluble CCR5 and CXCR4 proteins where functionally important regions of native receptors were connected with artificial linkers. These proteins were expressed in E.coli Origami 2(DE3) cells, refolded and purified. We have shown that recombinant proteins are functionally similar to native receptors since they bind to specific anti-CCR5 and anti-CXCR4 antibodies in immunoblot, immunoprecipitation and ELISA. Using the recombinant proteins for immunization we have obtained specific rabbit polyclonal serum. Finally, we established a competitive ELISA assay to search for the inhibitors of antigen and antibody binding. By applying this assay we perfomed screening of combinative drug library and found potential inhibitors.

\section{Discussion}

It is well known that CCR5 and CXCR4 chemokine receptors play a central role in the mechanism by which HIV binds to and enters white blood cells, and therefore represent key targets in the search for effective novel

* Correspondence: vkurbatska@gmail.com

${ }^{1}$ Latvian Biomedical Research and Study center, Riga, Latvia treatments for HIV infection and AIDS. The current results indicate that recombinant soluble chemokine receptors are functionally active and can be used in screening of potential HIV-1 inhibitors.

\section{Author details}

${ }^{1}$ Latvian Biomedical Research and Study center, Riga, Latvia. ${ }^{2}$ ASLA Biotech, Riga, Latvia. ${ }^{3}$ Bioactivity Ltd., Rehovot, Israel.

Published: 11 May 2010

doi:10.1186/1742-4690-7-S1-P44

Cite this article as: Kurbatska et al:: Recombinant soluble CCR5 AND

CXCR4 chemokine receptors as anti-HIV drug targets. Retrovirology 2010 7(Suppl 1):P44.
Submit your next manuscript to BioMed Central and take full advantage of:

- Convenient online submission

- Thorough peer review

- No space constraints or color figure charges

- Immediate publication on acceptance

- Inclusion in PubMed, CAS, Scopus and Google Scholar

- Research which is freely available for redistribution

Submit your manuscript at www.biomedcentral.com/submit 